Novum Testamentum XXXV, 4 (1993), (c) E.J. Brill, Leiden

\title{
THE SINNERS AND THE LAWLESS IN PSALM OF SOLOMON 17
}

\author{
by \\ JOHANNES TROMP \\ Leiden
}

Psalm of Solomon 17 is a prayer for the coming of a king from the family of David. In the first part of this Psalm of Solomon, vss. $1-20^{1}$, the reasons for this prayer are unfolded: Israel and Jerusalem are in a state of grave distress caused by the rule of impious men who have taken David's throne by force.

In this article it will be argued that in vss. 5-6 and 11-14 the author describes the situation he is living in, characterised by the rule of pagan tyrants. He interprets this situation as a divine punishment of the (entire) people's former sins. In contrast to the usual interpretation of Ps. Sol. 17, it will be shown that the rulers who have taken David's throne (vss. 4-6), and who are the author's contemporaries, are foreigners, and that they are the same foreigners whose lawless acts are described in vss. 11-14. Furthermore, it will be argued that no distinction is made in vss. 11-20 between a sinful people and a pious "remnant."

In this study I will at first leave out any considerations concerning possible historical references in the text. Scholars often appear to have forced a preconceived historical framework onto the text of Ps. Sol. 17. They derive this historical framework from the interpretation of other Psalms of Solomon, which are generally supposed to contain references to Pompey (Ps. Sol. 2 and 8, see especially

1 Unless indicated otherwise, the Greek text and the numeration of verses follow the edition of A. Rahlfs, Septuaginta, id est Vetus Testamentum graece iuxta LXX interpretes, Stuttgart 1935. For the Syriac, use has been made of the edition of W. Baars in The Old Testament in Syriac according to the Peshitta Version, IV, 6, Leiden 1972.

${ }^{2}$ This interpretation of Ps. Sol. 17:1-20 is not entirely new: some of its major features were already present in W. Frankenberg, Die Datienung der Psalmen Salomos. Ein Beitrag zur jüdischen Geschichte (BZAW 1), Giessen 1896. However, Frankenberg's conclusions, which have won little approval in subsequent scholarship, need substantiation and modification. 
2:26-27 and 8:15-20). Since the author of Ps. Sol. 17 refers in vss. $7-9$ to foreign rulers, it is often assumed that here, too, he is alluding to Pompey. ${ }^{3}$

It must be noted, however, that it is by no means certain that all Psalms of Solomon were written in approximately the same period. It is theoretically possible that Ps. Sol. 17 was written long before it was adopted into the collection as we now possess it. On the other hand, it is equally possible that Ps. Sol. 17 was written much later than other poems in the collection, and added to them in a later stage. In either case, the original meaning of Ps. Sol. 17 may be different from the one ascribed to it on the basis of its incorporation into the collection as we now have it.

Therefore, I have chosen to investigate the plain meaning and the structure, especially of the first part of Ps. Sol. 17, without reference to other Psalms of Solomon (sections I-IV, completed with an overview of the second part in section V). Only after interpreting Ps. Sol. 17 in itself shall I add some considerations with regard to its possible historical background (section VI).

\section{The Sinful Rulers in Ps. Sol. 17:1-20}

According to the common interpretation of Ps. Sol. 17, this poem displays strong connections with historical events and circumstances. Scholars have been quite confident in identifying the exact events and the figures playing a key role in them. According to their majority, Ps. Sol. 17:1-20 describes a succession of sinful rulers, domestic and alien respectively, as well as the reaction of a presumably small group of pious Jews, to be distinguished from the great majority of the Jews in Jerusalem.

The succession of sinful rulers described is usually interpreted as follows.

In the first place, it is supposed that vss. 5-6 mention people who have unrightfully seized dominion in Israel. Many scholars identify these men with the Hasmonean kings. ${ }^{4}$ An important basis for the

${ }^{3}$ A consequence of this line of thought is that, according to most exegetes, the illegitimate rulers described in vss. 5-6 must be the Hasmoneans, for it was they who preceded the coming of Pompey; see section I below.

+ See the major commentaries and studies by H.E. Ryle and M.R. James,

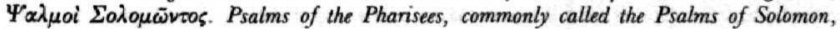


identification of the illegitimate kings with the Hasmoneans is the identification of the foreign ruler in vs. $7 \mathrm{~b}$ with Pompey (see below). The rulers preceding Pompey must then be the Hasmoneans. Next, it is argued that the Hasmoneans were not of Davidic descent, and that the throne which God had sworn to reserve for David's offspring (vs. 4b) was not promised to them (vs. 5b). For this reason the author would characterise the Hasmoneans as

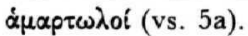

Second, it is almost generally assumed that vss. 7-9 describe the

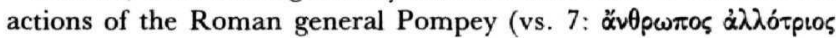

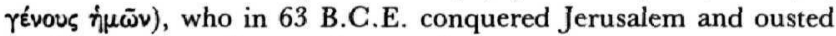
the Hasmoneans from real power. ${ }^{5}$

Finally, in vss. 11-14, Pompey would again be described, but now in his position as an instrument of God's wrath who has forgotten his subordinate role, and who acts arrogantly against God and his people. ${ }^{6}$ As such, Pompey would be designated as ó àvopos. The prayer to God that he may send a Davidic king who will rescue Israel would have been inspired by the resentment against the Roman invader.

Thus, Ps. Sol. 17 is commonly considered to describe (1) the succession of the sinful Hasmoneans, (2) their punishment by the hand of Pompey, who was himself a sinner, and (3) from vs. 21 onward, the (future) Davidic Messiah, who will remove Pompey and restore Israel to its former glorious state.

This widely-held interpretation, however, must be rejected for the following reason. In vss. 7-9a of the Greek text, future tense forms are used, which clearly indicate that the punishment of the illegitimate rulers has not yet taken place. This problem is usually discarded by means of the theory of the Hebrew original of the Psalms of Solomon. Thus, the future tenses in vss. 7-9a would be a clumsy translation of Hebrew imperfect forms, which can indicate

Cambridge 1891; R. Kittel, "Die Psalmen Salomos", in: E. Kautzsch (ed.), Die Apokryphen und Pseudepigraphen des Alten Testaments, II, Tübingen 1900, pp. 127-148; J. Viteau, Les Psaumes de Salomon, Paris 1911; J. Schüpphaus, Die Psalmen Salomos. Ein Zeugnis Jerusalemer Theologie und Frömmigkeit in der Mitte des vorchristlichen Jahrhunderts (ALGHJ 7), Leiden 1977.

${ }_{5}$ It has been objected by some that Pompey can hardly be said to have killed the entire Hasmonean family. Although this objection must not be discarded too easily, it is possible that we have to allow for some poetic exaggeration.

6 Again, Ps. Sol. 2 and 8 are used to provide parallels. 
past as well as future tenses. ${ }^{7}$ In vs. 9b, "correct" aorist forms,

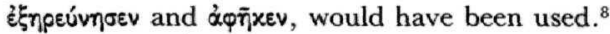

However, there is no objection against taking the future tense forms in the Greek text at face value. In that case, vss. 7-8 can be translated as follows:

But you, o God, will bring them down and remove their offspring from the earth when there rises up against them a man foreign to our race.

You will repay them, o God, according to their sins, so that it will befall them according to their dealings.

This call for revenge is continued in vs. 9, with a seemingly peculiar alternation of tenses in the Greek text: ${ }^{9}$

According to their dealings, ${ }^{10}$ God will not ${ }^{11}$ have mercy on them: ${ }^{12}$ he has found their offspring and has let none of their seed go. ${ }^{13}$

' So for instance R. Kittel, Apokryphen und Pseudepigraphen, p. 145; G.B. Gray, "The Psalms of Solomon", in: R.H. Charles (ed.), The Apocrypha and Pseudepigrapha of the Old Testament, II, Oxford 1913, p. 648; R.B. Wright, in: J.H. Charlesworth (ed.), The Old Testament Pseudepigrapha, II, London 1985, p. 666; P. Prigent, in: A. Dupont-Sommer; M. Philonenko (eds.), La Bible. Ecrits Intertestamentaires (Bibliothèque de la Pléiade), Paris 1987, p. 985; A. Piñero Sáenz, in: A. Díez Macho et alii, Apócrifos del Antiguo Testamento, III, Madrid 1982, p. 50. Viteau, Les Psaumes de Salomon, p. 343, favoured this solution as well, but he also offered an alternative solution-according to Viteau, the mixture of past and future tenses might reflect the indignation of the author, who was convinced that the punishment, already begun with the fall of Aristobulus, would continue to extinguish the entire Hasmonean family. A similar view was expressed by $\mathbf{M}$. de Jonge, "The Expectation of the Future in the Psalms of Solomon"' (Dutch 1965), now in: Jewish Eschatology, Early Christian Christology and the Testaments of the Twelve Patriarchs. Collected Essays of Marinus de Jonge, edited by H.J. de Jonge (SNT 63), Leiden 1991, pp. 3-27, esp. pp. 9-10; see also his "The Psalms of Solomon", in: M. de Jonge (ed.), Outside the Old Testament (Cambridge Commentaries on Writings of the Jewish and Christian World 4), Cambridge 1985, p. 173.

${ }^{8}$ Contrast, however, Frankenberg, Die Datierung, p. 43, who regards Ps. Sol. 17:7-10 as a reference to the future, and comments: "V. 7-10 enthalten also nicht eine Schilderung der Gegenwart des Verfassers, sondern geben ein Bild des erwarteten Gerichtes über die Heiden; die vereinzelten beiden tempora perfecta in v. 9 kommen auf Rechnung des griechischen Übersetzers'". So also S. HolmNielsen, in: W.G. Kümmel et alii (eds.), Jüdische Schriften aus hellenistisch-römischer Zeit, IV/2, Gütersloh 1977, p. 99; Holm-Nielsen calls the aorist in vs. 9 "'falsch".

${ }^{9}$ To the scholars who retain the transition from future to aorist tense in their translations belong J.P. Migne, Dictionnaire des apocryphes, I, Paris 1856, col. 952; M.-J. Lagrange, Le Judaisme avant Jésus-Christ, Paris ${ }^{3} 1931$, p. 153; M. de Jonge, "The Psalms of Solomon", p. 169; and S.P. Brock, in: H.F.D. Sparks (ed.), The Apocryphal Old Testament, p. 67.

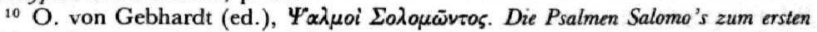
Male mit Benutzung der Athoshandschrifien und des Codex Casanatensis herausgegeben, Leipzig 1895 , pp. $52-53,129$, preferred the reading offered by $\mathrm{ms} 253$, and supported by the Syriac version (which is related to $\mathrm{ms} 253$ according to J.L. Trafton, The Syriac Version of the Psaims of Solomon. A Critical Evaluation [SCS 11], Atlanta 1985), 


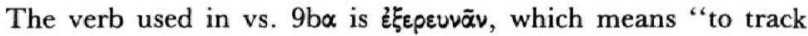
down." 14 In this instance, the verb designates the search that immediately precedes the actual revenge God will execute. ${ }^{15}$

This usage of $\varepsilon_{\xi} \xi \rho \varepsilon u v \tilde{\alpha} \nu$ can be illustrated by the following examples from the Greek Bible. In 1 Macc. 3:5 it is said of Judas

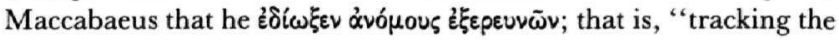
lawless ones down, he chased them." In Amos 9:1-3 the prophet claims to have seen the Lord at the altar, threatening the sinners that he would come to punish them. They may try to hide, but if they hide in Hades, his hand would haul them up, and if they hide in heaven, he would tear them down. "If they try to hide on the top of Mount Carmel, I will track them down from there, and I will

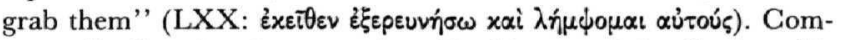
pare, finally, the threat against David uttered by Saul to his companions in 1 Sam. 23:23: "If he (David) is in the land, I shall track him down ( $\xi \xi \varepsilon \rho \varepsilon v i \eta \omega \omega)$ among (or: with) all the thousands of

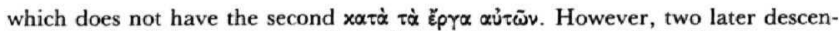
dants of the 253-group, as well as all the other branches of the Greek stemma include the second $x \alpha \tau \dot{\alpha} \tau \dot{\alpha}$ ĕ $p \gamma \alpha \alpha \dot{v} \tau \bar{\omega} v$. Apart from the fact that the inclusion of

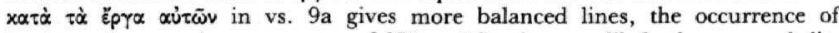
haplography once in an ancestor of 253 and Syr is more likely than several dittographies in different branches. The longer reading is accepted by Ryle and James, as well as by Wright, in: The Old Testament Pseudepigrapha, II, p. 666.

11 Ryle and James omit oux, in accordance with the reading offered by the 260group. The textual witnesses (including the Syriac) as well as the context strongly argue against their reading.

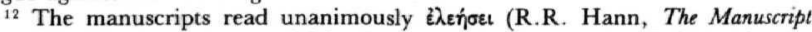
History of the Psalms of Solomon [SCS 13], Chico 1982, p. 30). Von Gebhardt's conjecture $\dot{\eta} \lambda$ én is rejected by most scholars, since it does not solve the problem, but only moves it to another place.

13 The Syriac text has: "Do not have mercy on them, o God; Visit their seed and do not leave even one of them" (trans. Trafton, The Syriac Version, p. 157). K.G. Kuhn, Die älteste Textgestalt der Psalmen Salomos insbesondere auf Grund der syrischen Übersetzung neu untersucht (BWANT 4, 21), Stuttgart 1937, pp. 58-60, argued that the Greek text is a mistranslation of a partly corrupt Hebrew original, and that the Syriac is a correct translation of a correct Hebrew original. However, the smoothness of the Syriac text, here and in other places in Ps. Sol. 17, raises doubt with regard to its chances of reflecting the original reading better than the Greek (see J. Begrich, "Der Text der Psalmen Salomos", ZNW 38 [1939], pp. 131-164, esp. pp. 131-152, and R.B. Wright, review of Trafton, The Syriac Version, JBL 107 [1988], pp. 131-134).

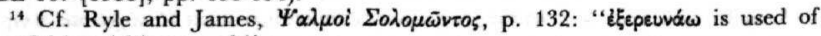
careful inquisitive search".

${ }_{15}$ P. Rießler, Altjüdisches Schriftum außerhalb der Bibel, Tübingen 1928, p. 898, wrongly translates "vertilgen" ("to destroy"). 
Judah." In the following account it is related how Saul finds out time and again where David is, and then chases ( $x \alpha \tau \alpha \delta \dot{\delta} \omega x \in t v)$ him when David appears to have fled (1 Sam. 23:25-26).

In these instances $\varepsilon_{\xi} \xi \varepsilon \rho \varepsilon u v \tilde{\alpha} \nu$ signifies the preparatory search of someone's enemy, before chasing, grabbing, or killing him. ${ }^{16}$ In Ps. Sol. 17:9b the aorist éFnpeúvnoev implies that God has completed the search for the illegitimate rulers: he has found them all. The following aorist tense, "and he let go ( $\alpha \varphi \tilde{\eta} \times \varepsilon v)$ none of their offspring", suggests that God has already laid his hands upon them, without letting a single sinner escape. ${ }^{17} \mathrm{He}$ is therefore ready to exact the retribution the author prays for; the author is convinced that God will presently proceed to action, and will destroy every single sinner.

A similar image, expressing that the Lord has found his enemy, and that he has made the necessary preparations to punish him, occurs in Jeremiah's prophecy against Babylon, Jer. 50 (27LXX):24-25:

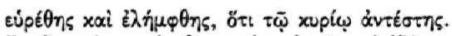

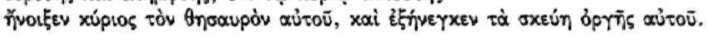

You have been found and you have been grabbed, for you withstood the Lord. The Lord has opened his armoury, and he has taken out the weapons of his wrath.

Another example can be found in Ps. 7:13-14(LXX), where the Lord is described as having made the preparations for his imminent punishment:

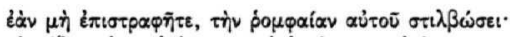

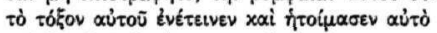

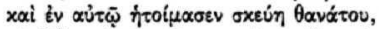

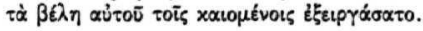

If you do not repent, he will whet his sword:

he has strung his bow and prepared it,

and with it, he has prepared instruments of death,

he has made his arrows ready for them to be burnt.

A comparable usage can also be found in Isa. 30:33 (the Lord has prepared a burning place for the Assyrian), and in Zach. 9:13-14 (the Lord has bent Judah as his bow, and his arrow will go forth like lightning).

${ }^{16}$ For "chasing, grabbing, and killing"' see also Ps. Sol. 15:7-9.

17 For this meaning of détevvou see for instance Ps. 105(104LXX):20; Cant. 3:4. 
This interpretation of vss. 7-9 accounts for both the future tenses in vss. $7-9 \mathrm{a}$ and the past tenses in vs. $9 \mathrm{~b}$. The punishment of the

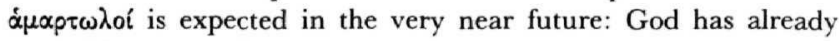
made his preparations.

Furthermore, there is no reason to regard the sinful rulers of vss. 5-6 as Judean rulers, or as the Hasmoneans in particular; ${ }^{18}$ it is more likely that foreign rulers are meant. First, jt seems somewhat odd that the author would pray for the total destruction of the Hasmonean high priests and kings by foreign intruders, even if he were opposed to them; sinful or not, the Hasmoneans were at least Judeans. Moreover, the second part of Ps. Sol. 17, vss. 21-45, continuously alternates between "nations" and "sinners", ${ }^{19}$ clearly referring to only one enemy (namely, the foreign invaders), and not to foreigners on the one hand and Jewish sinners on the other. There is no cogent reason to assume that things are different in the first part of the poem. The possible identity of these foreign oppressors will be discussed in section VI.

According to Ps. Sol. 17:7b, the author expects God to take vengeance through a foreigner; that is, he hopes for another foreigner to destroy the present foreign power. ${ }^{20}$ Likewise, the author of Ps. 137(136LXX):8-9, who is an exile in Babylon, seems to consider such a possibility as the only basis for hope:

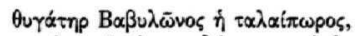

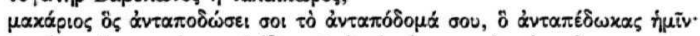

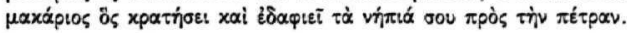

You miserable daughter of Babylon, happy is he who repays to you the retribution, the things you have exacted from us; happy is he who takes your children and smashes them against the rock.

Prophecies of the exile, such as those of Jeremiah and DeuteroIsaiah, often voice the expectation of a foreign nation to destroy Babylon. It is possible, then, that the author of Ps. Sol. 17 had set

18 Wright, The Old Testament Pseudepigrapha, II, p. 665.

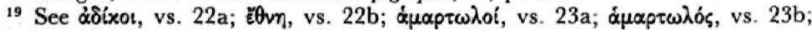
$\varepsilon \theta v \eta$, vs. $25 \mathrm{a}$; $\alpha \mu \alpha p \tau \omega \lambda$ of́, vs. $25 \mathrm{~b}$.

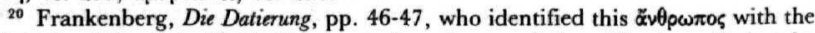
Messiah of Ps. Sol. 17:21-43, objected to the translation "foreigner", but he offered no alternative (cf. his remark on p. 47: "Jedenfalls aber wäre es eine verkehrte Methode, wenn man diese zweifellos unklaren Worte dazu benutzen wollte, um eine geschichtliche Situation zu substituieren, die in den zweifellos klaren Worten des Psalmes keinerlei Anhalt hat'). The Syriac version (17:9 gbr $n w k r y{ }^{\prime} m n$ śrbt $t^{\mathrm{c}} d y(n)$ supports the usual translation. 
his hope on a particular enemy with which the foreign ruler had to deal in his time; see section VI.

In vs. 11 a passage begins in which the actions of $\dot{o}$ ávopos (with the definite article) are described. This "lawless one" is usually identified with the foreigner in vs. $7 \mathrm{~b}$. However, the punishment which this foreigner executes is expected in the future, whereas the actions of the óvouos are described in the past tense, just like the actions of the $\alpha \mu \alpha p \tau \omega \lambda \alpha^{\prime}$ in vs. 5. It must therefore be concluded that the $\alpha^{\prime}$ voros and the $\alpha \mu \alpha p \tau \omega \lambda$ oi are the same people, and that after the cesura marked by the doxology in vs. 10 , vs. 11 resumes the subject matter discussed in vs. 5 (see below, section III).

\section{The Pious People in Ps. Sol. 17:11-20}

It is often assumed that in Ps. Sol. 17:11-20 three persons or groups are described: (1) a foreign ăvouos in verses 11-14; (2) the

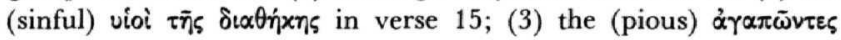
$\sigma u v \alpha \gamma \omega \gamma \alpha \dot{\zeta} \zeta \sigma i \omega v$, who fled into the desert according to vss. 16-18a. It is generally agreed that there is a causal connection between the sins of the "sons of the covenant" and the coming of the lawless one (cf. again vs. 5a). But many scholars also consider "those who love the gatherings of the holy ones" as a group that regarded itself as distinct from "the sons of the covenant", being innocent of the latter's sins and taking refuge from the abomination into which their co-religionists had turned Jerusalem.

Serious objections against this view must be made.

(1) There are no sufficient grounds to distinguish between oi vioi

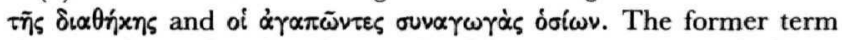
clearly refers to Israel as the people of the covenant, ${ }^{21}$ and the latter designates the cultic community. ${ }^{22}$ In other words, in both cases, the Jews in Jerusalem are meant, and we are dealing here with a normal synonymous parallelism.

${ }^{21}$ For the expression "sons of the covenant", see 1 QM XVII 8; Acts 3:25.

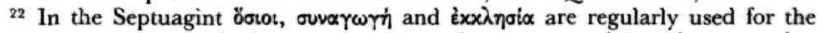

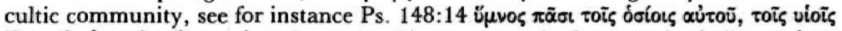

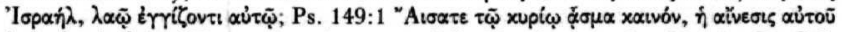

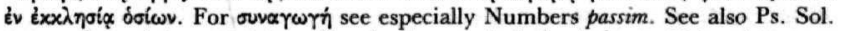

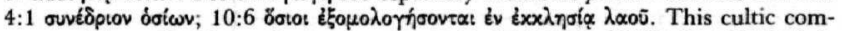
munity "loves God", see for instance Ps. $5: 11 ; 31(30): 23 ; 69(68): 36 ; 122(121): 6$; 145(144):20; Isa. 66:10; Lam. 1:2; those who belong to this cultic community "love" its gatherings in the temple, compare Ps. 26:8; 84:1-4. 
(2) The ones "who love the holy gatherings" are said to flee like alarmed sparrows (vs. 16b), ${ }^{23}$ and to err in the desert to save their lives "from the catastrophe" (ámò xoxoũ, vs. $17 \mathrm{a}^{24}$ ). The image used for sudden fear, and the expression of the urgent need to save one's life in the desert (cf. vs. 17b) are more appropriate of an escape from a foreign military power who conquers the city, than of a retreat into the desert in order to avoid the urban defilement. This interpretation is corroborated by vs. $18 \mathrm{a}$, where it is said that "their dispersion" was caused i $\pi$ ò àvó $\mu \omega \nu$, which seems a clear reference to the ăvouos of vs. 11 . Moreover, in vs. 5 the sinners are also said to have "driven us out".

(3) Finally, it is said in vs. 15b as well as in vss. $19 \mathrm{~b}-20$ (shortly after the mention of the escape from Jerusalem) that there were no exceptions to the general sinfulness of the inhabitants of the city. ${ }^{25}$ Indeed, vs. 20 places heavy stress on the fact that each and every man, from the leaders to the most humble, the king, the judge and the entire people, were év $\pi \dot{\alpha} \sigma n \dot{\alpha} \mu \alpha \rho \tau i$. This agrees with vs. 5a: '́v

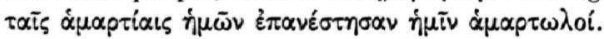

The simplest explanation of vss. 15-20 is to regard this passage as a description of the sinfulness of the entire people, which has led to the coming of a foreign power. His actions, clearly a divine punishment of the people (and defined as such in vs. 15b), were so terribly cruel, that the people had to flee and were thankful for any survivors from his hand (vss. 16-18). ${ }^{26}$ In vss. 15-20 there are therefore two motives brought forward to move God to mercy: (1) the recognition of the sinfulness of the people as the cause of the present miserable situation; (2) the miserable situation itself, which is described in order to show that the chastisement has been executed and the punishment fulfilled. These two elements often occur together in confessional prayers. ${ }^{27}$ In the Psalms of Solomon one may compare especially 2:19-25 after 2:3-18.

${ }^{23}$ When the nests of sparrows are disturbed, these nervous birds seems to hover

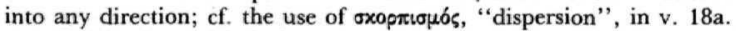

${ }^{24}$ Frankenberg, Die Datierung, p. 40, interprets: they have fled in order to save their souls dimò xaxoũ, that is, in order to safeguard their dxxaxia, their innocence. Syriac by (s' also covers both meanings.

${ }_{25}$ Viteau, Les Psaumes de Salomon, p. 347, acknowledges that this is the intention of vss. 15-20, but on p. 348 he still distinguishes the ones who love the holy gatherings ("par exemple les pharisiens") from the other inhabitants of Jerusalem.

${ }_{26}$ For the phrasing of vs. $17 \mathrm{~b}$, see the parallels adduced by Begrich, Der Text, p. 148: 1 Sam. 26:21; 2 Ki. 1:13-14; Ps. 48(49LXX):9; 116:15(115:6LXX).

${ }^{27}$ On this literary form, see C. Giraudo, La struttura letteraria della preghiera 
This interpretation may raise the question why a people that is described as extremely sinful is also labeled with such honorary designations as "sons of the covenant" and "those who love the holy gatherings". The answer must be that the author refers to himself and to those on whose behalf he writes in the third person plural, a well-known device to express humility and submissiveness when speaking to a person who is of higher rank, for instance, a king, or, as in this case, God. Also, the designation used by a speaker to refer to him- or herself can serve to specify the relationship to the addressee in which the speaker stands, in this case a covenantal relationship. ${ }^{28}$

A famous example of this use of the third person to refer to the speaker himself is the speech of the Tekoite woman (2 Sam. 14). She not only addresses king David in the third person, calling him " "my lord", but also refers to herself in the third person, "your servant". In the biblical Psalms and in other prayers, many instances of this device can be found. Apart from the many instances in which the praying people refer to themselves as God's people or his servants (or similar designations), several passages may especially be noted.

Ps. 74(73LXX) is a lament because of the destruction brought by a foreign invader, in which the people refer to themselves as the sheep of God's pasture (vs. 1), God's congregation (vs. 2), God's turtledove and his poor congregation (vs. 19; compare the

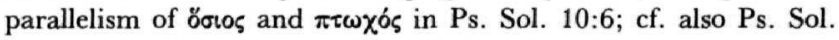
15:1). These descriptive self-designations express the people's powerlessness and their special relationship to God. In Neh. 1:5-11 Nehemiah is described as praying on behalf of the sinful people,

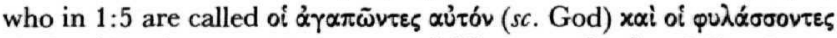

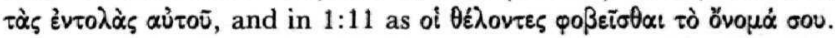
Here we find the combination of a confession of sins, the expression of a special relation, and the people's intention to act according to God's will. Two passages from the Psalms of Solomon can also be

eucaristica. Saggio sulla genesi letteraria di una forma (Analecta Biblica 92), Rome 1981; also J. Tromp, The Assumption of Moses. A Critical Edition with Commentary (SVTP 10), Leiden 1993, pp. 164-165.

${ }_{28}$ The comparison with frightened sparrows (vs. 16) serves a similar goal: it points to the people's powerlessness with regard to the foreign tyrant, and to the help from God they urgently need. 
mentioned in this connection: in Ps. Sol. 10:3 and 14:1 the ones who love God express their gratitude for his chastisement.

Thus in Ps. Sol. 17:15, 16 the author refers to himself and to those that belong with him with the expressions "sons of the covenant" and "the ones who love the holy gatherings". The use of the third person is a form of politeness, whereas the expression itself draws attention to the special relationship in which the sinful people stand to their God.

\section{The Structure of Ps. Sol. 17:1-20}

A major advantage of taking vss. $7-9 a$ as referring to the future is that we can see Ps. Sol. 17 as a unified whole. This contrasts significantly with the common interpretation, which resists a satisfactory formal analysis because it regards a major part of the Psalm as being primarily an enumeration of subsequent historical events. ${ }^{29}$

Whereas Ps. Sol. 17 evidently consists of two main parts, vss. 120 and vss. 21-45, it is now also clear that the first main part can, in its turn, be subdivided in vss. 1-10 and vss. 11-20.

Ps. Sol. 17:1-10 is structured as a traditional national complaint. There are three sections which are formally distinguished by an

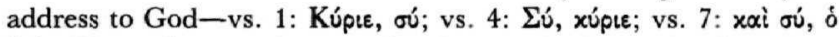
$\theta \varepsilon o ́ \zeta$. These three sections can be characterized as a doxology (vss. 1-3), a lament (vss. 4-6), and an expression of confidence in God's intervention (vss. 7-9). A short praise of the Lord concludes this first part of the poem. A brief discussion of its constituent parts is in order.

(a) The doxology in vss. 1-3 praises the Lord as the true king of Israel ("Lord, you are yourself our king"). The eternal character of his kingship is contrasted with the brief life of man. This contrast serves to illustrate the reliability of God as opposed to the insignificance of human efforts: our hope, the author says, is vested not in man, but in the eternal, mighty God. He will rule his people with mercy, and the nations with justice.

(b) Having thus placed his fate and his hopes into the hands of God, the author laments on behalf of his people about the upsetting

29 Contrast Schüpphaus, Die Psalmen Salomos, p. 64: "ein formal sehr uneinheitliches Textgebilde". 
of the earthly kingship of Israel (vss. 4-6). God has sworn that the descendants of his chosen king David would rule forever, but sinful people, to whom nothing was promised, have taken David's throne by force because of "our" sins.

(c) In the text passage (vss. 7-9), no imperative is used, but the future tense. This use of the future tense expresses that the author knows for sure that God will act in the way he is asked (see section I). This passage therefore takes the place of the plea. ${ }^{30}$ The author expects God to remove the sinful occupants of David's throne by sending "a foreign man". Through this man, God will punish the rulers and their progeny for their sins. Turning to the third person, the author says that God will not have mercy on them.

(d) Finally, God is praised as faithful; the motifs of his righteousness as well as his reliability are reiterated (vs. 10).

The next passage, vss. 11-20, consists of three parts, although the distinction between these parts is less clear than it is in vss. 1-10. The clarity may have suffered from mishaps in the textual transmission (see the short excursus under b below).

(a) Vss. 11-14 describe the murderous rule of the lawless one, but they also seem to rationalise his behaviour. It is said that the enemy was a foreigner and as such could not have known our God (vs. 13). Moreover, he acted as the nations are accustomed to act (vs. 14). ${ }^{31}$

(b) In vss. 15-18a the foreigner's reign appears relatively inno-

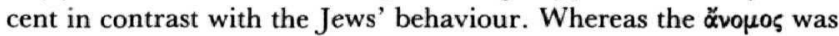
a foreigner and did not know God, the "sons of the covenant" (vs. 15) did know God, and to that extent were even more sinful than the one who, so to speak, could not help his own criminal behaviour.

The meaning of $x \alpha i \dot{\varepsilon} \pi \varepsilon x p \alpha \tau \sigma \tilde{u} \sigma \alpha v \propto \dot{v}^{\prime} \tau \bar{\omega} v$ in vs. 15 is disputed. ${ }^{32}$ It is customary to take the "sons of the covenant" as the subject of this clause. However, the clause then hardly makes sense-how can be Jews be said to "rule" over the foreigners (so Viteau's translation)? A number of scholars translate the clause as: "and the sons of the covenant surpassed" the foreigners, namely in sinfulness, ${ }^{33}$ but

30 The Syriac version, which probably is secondary, does have imperatives (see above).

${ }^{31}$ Kuhn, Die älteste Textgestalt, pp. $64-65$, considered this passage to be a later addition.

${ }_{32}$ The Syriac has 'hydyn hww lhwn, which has the appearance of translating the Greek literally, not clarifying it.

${ }^{33}$ So Ryle and James, comparing Ps. Sol. 1:8 and 8:13. 
èrexpazeĩ does not mean "to surpass". I suggest to read a full stop following $\dot{\varepsilon} \pi \varepsilon \times \rho \alpha \tau o \tilde{\sigma} \sigma \alpha v \alpha \dot{\tau} \tau \bar{\omega} v,{ }^{34}$ and to regard the foreigners as the subject of this phrase; the objective genitive $\alpha \dot{\tau} \tau \bar{\omega} v$ then refers to the inhabitants of Jerusalem (in a paraphrase: these foreigners just described, held them, the Jews, in their power). A new sentence begins with oi vioi $\tau_{\bar{\eta}} \delta \delta \alpha \theta \dot{j} \times \eta \eta_{\zeta} \times \tau \lambda$.; this phrase can then be taken

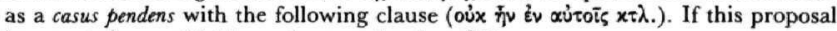
is accepted, vss. 14-15 can be translated as follows:

(14) And everything he did in Jerusalem

he did in accordance with the way the nations act in the cities to their gods,

$(15 a \alpha)$ and they held them in their power. ${ }^{35}$

(15aß) As to the sons of the covenant, in the midst of all kinds of nations,

(15b) there was no one among them in Jerusalem who acted in mercy and truth.

Because of their sinfulness, God sent the foreign ruler; "those who love the gatherings of the holy ones" had to flee, deeming themselves happy if any of them survived the catastrophe.

(c) Finally, the motif of the all-surpassing sinfulness of the inhabitants of Jerusalem (vs. 15) is repeated in vss. 18b-20. The sheer boundlessness of their crimes (there are no virtuous exceptions among the sinners in Jerusalem, vs. 20$)^{36}$ makes heaven and earth loathe them (vss. 18b-19). ${ }^{37}$

This analysis of vss. 11-20 shows that this passage is an expansion of the theme announced in vss. 4-6, the short complaint in the introductory section of Ps. Sol. 17. The ävouos in vs. 11 is identical to the $\alpha \mu \alpha \rho \tau \omega \lambda$ oi in vs. $5,{ }^{38}$ and not to the foreigner who will come

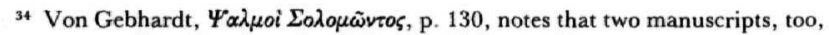
punctuate at this point (mss $J$ and $V$, now 336 and 149).

35 This translation attempts to render the durative aspect of the imperfect form

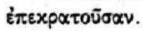

36 The mention of a king in vs. $20 \mathrm{~b}$ has been taken as a confirmation of the dating of this poem in the time immediately following the Hasmonean kingdom (see for instance Schüpphaus, Die Psalmen Salomos, p. 71). However, the author must rather be understood as using a traditional enumeration of offices, which enumeration serves to illustrate that the sinfulness described is to be found in all layers of society. For similar enumerations, cf. Tromp, The Assumption of Moses, pp. 186-187.

s? It has been suggested, for instance, by Hilgenfeld, " Die Psalmen Salomo's und die Himmelfahrt des Moses, griechisch hergestellt und erklärt', Zeitschrift für wissenschaftliche Theologie 11 (1868), p. 166, and by Schüpphaus, Die Psalmen Salomos, p. 70 , that vss. $18 \mathrm{~b}-19 \mathrm{a}$ refer to a real drought; but the image should rather be interpreted in the light of similar expressions, as in Ps. Sol. 2:9.

38 The difference in number (one "lawless one" versus more than one "sinners') is irrelevant. The words ävouos as well as é $\chi 0$ pós (vs. 13a) designate a collec-

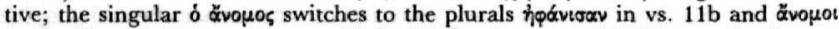

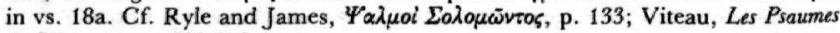
de Salomon, pp. 344-345. 
to punish the $\dot{\alpha} \mu \alpha p \tau \omega \lambda$ o! (vs. 7). Both vss. 4-6 and 11-20 describe the author's present situation. ${ }^{39}$

\section{Summary of Ps. Sol. 17:1-20}

(a) In vss. 1-3 the author of Ps. Sol. 17 praises God as the true king, and as the only one who can save Israel. In vss. 4-6 the present situation of the land is contrasted with God's promises concerning David's kingship: instead of a son of David, foreign sinners rule over Israel. These sinners have driven the people away and have taken David's throne by force, without paying honour to God's name. The sins committed by the Jews themselves are mentioned as the cause of the advent of the enemy. In vss. 7-9 the author expresses his confidence that the Lord will hear his prayer and will destroy the foreign intruders. The instrument the author expects God to use is a foreign man as well. A formula of faith closes this section (vs. 10).

(b) In the second part (vss. 11-20), the lament of vss. 4-6 is elaborated. In vss. 11-12 the cruel measures the lawless one takes against the people are described. In vss. 13-14 his cruelty and hubris are explained by the fact that he is a foreigner, and does not know God. In vs. 15 the sins the pagan ruler has committed are contrasted to the even graver transgressions of Jerusalem's inhabitants themselves. In this connection the Jews are called "sons of the covenant", which stresses the special relationship between God and his people. Because of this relationship their sins may be regarded as all the more reprehensible. But this relationship also forms the basis for them to ask for pardon. In vss. 16-18a the great distress in which the people now live is depicted (again, in order to make God relent, the people are given a name which expresses their desire to be pious): they had to flee into the desert to save their lives and, because of the lawless ones, they are dispersed throughout the land. A renewed confession of sin (vss. 18b-20) concludes the lament, which is eventually to be followed by the long prayer for the reinstalment of a son of David on Israel's throne (vss. 21-45).

\footnotetext{
39 Frankenberg, Die Datierung, p. 38; so also Schüpphaus, Die Psalmen Salomos, p. 68.
} 
V. Ps. Sol. 17:21-45

A few words must be said about the relationship between the prayer for the Davidic king and the first part of Ps. Sol. 17. I will highlight several elements from that prayer, and show how they relate to vss. 1-20.

In Ps. Sol. 17:21-25 God is asked to raise a son of David who will " smash the unrighteous leaders, purge Jerusalem from the nations that trample around bringing destruction" (vs. 22). ${ }^{40} \mathrm{He}$ will

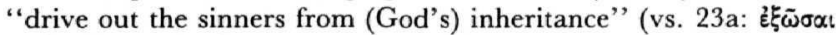

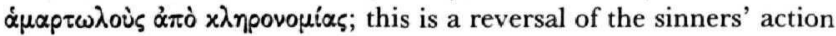
described in vs. 5b). He will also "break the pride of the sinner"

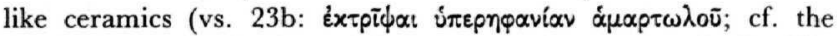
emphasis on the foreigners' hubris in both vss. 6 and 13). The nations and the sinners will be killed and made to flee (vss. 24-25; cf. vss. 11-18a). It is clear that this Davidic king will return to the nations exactly what they have done unto Israel.

In vss. 26-29 the author speaks about the holiness of the people in the time of the Davidic king: "there will be no more unrighteousness among them ... because all will be sons of God"' (vs. 27; cf. vs. 32: "all will be holy"). Clearly, this is a purified people. But the purification does not result from the destruction of the sinful Jews, for, according to vss. 15-20, the entire people was sinful. Rather, this purification is the result of the people's return to God, of which this very psalm is intended as a token. ${ }^{41}$ The same people who pray in Ps. Sol. 17 for a Davidic Messiah also promise

${ }^{40}$ It is true, as Frankenberg, Die Datierung, p. 46, suggests, that one would expect that the vindicator in vs. 7 and the Davidic Messiah would be the same person (just as the sinners in vss. 4-6 and 11-20 are the same persons). This incongruency may be explained by the fact that the author believed the coming of a new foreign power to be imminent, whereas the time of the advent of the Davidic king is deliberately left vague-the author prophesies the coming of another foreign power, but prays for the coming of a son of David (see vs. 21, where the author explicitly leaves the xaipó of the Messiah's advent to God; $\mathrm{cf}$. Schüpphaus, p. 70; and vs. 44, where the blessing of those "who will live in those days" equally does not seem to express a belief in the nearness of the coming of this king). $\mathbf{H}$. Ludin Jansen, Die spätjüdische Psalmendichtung. Ihr Entstehungskreis und ihr 'Sitz im Leben', Oslo 1937, p. 43, comments on Ps. Sol. 17:21-43: 'Diese 'Prophetie' ist keine eigentliche Prophetie, aber eine gelehrte, die Schriften deutende Verkündigung".

${ }^{41}$ Cf. M. de Jonge, "The Expectation of the Future", p. 12: "[The aim and intention] is the realisation of God's purpose on this earth, thoroughly cleansed and totally changed by God, with Jerusalem as its centre." 
to be pure and righteous in the future; ${ }^{42}$ it is the foreigners and sojourners that will then be removed (vs. 28). During the reign of this Davidic king, the nations will come humbly to be subdued; his kingdom will be glorious, and Jerusalem will be pure and holy "as in the beginning" (vs. 30).

The author proceeds with a description of the subjugation of the nations (vss. 30-31). Then he depicts the peaceful, yet safe, existence of the people under the Messiah's rule, which is due to his and the people's trust in God (vss. 32-43). Finally, he concludes his prayer with the exclamation that "happy will be the ones who live in those days!" (vs. 44). Vss. 45-46 round off the Psalm: God is asked to show his mercy swiftly (vs. 45a), and save the people from the impurity of the abominable enemies (vs. 45b). The last verse is an almost literal repetition of the opening line: "The Lord himself is our king for ever and ever."

This short overview of Ps. Sol. 17:21-46 shows the inner consistency of Ps. Sol. 17 as a whole, and confirms our findings as summarized in section IV.

\section{The Historical Background of Ps. Sol. 17}

For reasons set out in the introduction to this article, I have so far studied Ps. Sol. 17 mainly from a literary and traditio-historical point of view, without presupposing any particular historical events to which passages from this poem might refer. However, the interpretation of the poem proposed above does allow us to consider a small number of historical references.

(1) In vs. 7b the author expresses his firm belief that God will soon punish the sinners. He expects this intervention to be so near, that he can say that the Lord has already made the necessary preparations and holds the lawless in his hands-it is now only a matter of striking them dead. It is probable that international political developments raised such high-strung expectations. The analogies with Deutero-Isaiah and Jeremiah, who equally expected another foreigner to remove the present tyrant (see above), may illustrate this point.

${ }^{42}$ There is a possible reference to sinful Jews in the time of the Davidic Messiah in vs. 36. In that context, however, the removal of these sinners is an aspect of the perfect purity of the people in the Messianic time: the king will not allow sin to rise again. 
(2) The description of the sinful actions of the lawless one in vss. 11-12 is of a traditional nature. The author rebukes the foreign ruler for having killed on a massive scale, sparing neither the old nor the young. He also rebukes the ruler for having led the people into exile and for having brought the leaders to shame. These are actions commonly ascribed to any foreign intruder.

There are grave difficulties in the interpretation of vs. 12a, है

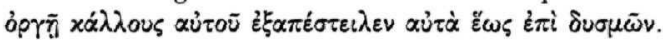

The genitive $x \alpha \lambda \lambda$ ous is generally considered to be wrong, but the manuscripts offer no alternative. ${ }^{43}$ If we abstain from translating the word back into Hebrew (and assume that the Hebrew was corrupt or misunderstood), we might suggest to understand $x a ́ \lambda \lambda$ ous as a genitive of motivation modifying óprị: "out of anger

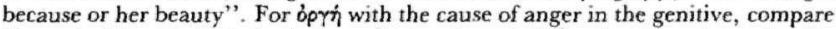

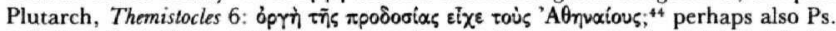

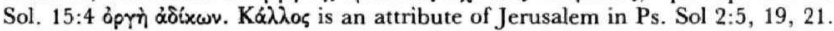

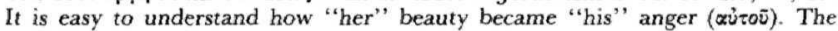
meaning would be that the foreigner was enraged with envy because of

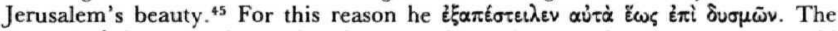
neutral aùtó must refer to the téxva mentioned in vs. $11 \mathrm{~b}$, whereas one would expect aùtoús to refer to all groups mentioned in that line. It may nevertheless be assumed that the meaning is that the entire population was led into exile. In descriptions such as these, it is not unusual for the author to have the "entire" population killed and be led off in captivity as well.

However, whatever the exact meaning of vs. $12 \mathrm{a}$ is, it is clear that the author intends to say that the population of Jerusalem was led into exile. It is important to note that he leads them off "to the West". This means that the enemy referred to is located to the West of Palestine. There is, as far as I can see, only one possible power to whom this may refer: Rome. ${ }^{46}$ It can therefore be concluded that the lawless ruler of vss. 5-6 and 11-15 must be identified with the Romans.

If international political developments must explain the expectation of another foreign power to overthrow the Roman rule (an expectation expressed in vss. 7-9) the likely candidate is the Par-

43 The Syriac version follows the Greek.

${ }^{44}$ Quoted in Liddell and Scott's Lexicon s.v. bprí. Compare perhaps

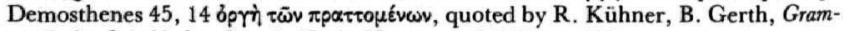
matik der Griechischen Sprache II, 1, Hannover '1898, p. 333.

${ }^{45}$ For envy as a motivation to attack Jerusalem, compare for instance Sib. Or. III 657-662.

${ }^{46}$ Theoretically, Greece (or Macedonia) may have been intended, but not the Seleucid empire (which is in the East), nor the Ptolemaic empire (which is in the South). For Rome as an enemy from the West, cf. As. Mos. 6:8. 
thians. Only the Parthians have formed a real threat to the Roman rule in this part of the world. They invaded Palestine in 40 B.C.E. ${ }^{47}$ and remained a serious rival to Rome throughout the following centuries. ${ }^{48}$ An exact date for Ps. Sol. 17 cannot be deduced from these data, but it is at least possible to conceive the historical circumstances leading to the expectations formulated in the poem.

47 See, e.g., G. Vermes et alii, revision and edition of E. Schürer, The History of the Jewish People in the Age of Jesus Christ I, Edinburgh 1973, p. 251.

${ }^{48}$ See E.M. Smallwood, The Jews under Roman Rule from Pompey to Diocletian. A Study in Political Relations (SJLA 20), Leiden ${ }^{2} 1981$, pp. 397 and 426 (footnote 151): in the second century C.E. "Palestinian Jews looked upon the Parthians ... as potential saviours"'. Smallwood quotes R. Simeon b. Yohai, who attached messianic expectations to the possible intervention of the Parthians. 